Article

\title{
Sol-Gel Hydrothermal Synthesis and Visible Light Photocatalytic Degradation Performance of Fe/N Codoped $\mathrm{TiO}_{2}$ Catalysts
}

\author{
Hsu-Hui Cheng ${ }^{1,2}, *(\mathbb{D})$, Shiao-Shing Chen ${ }^{3}$, Sih-Yin Yang ${ }^{3}$, Hui-Ming Liu ${ }^{1}$ and \\ Kuang-Shan Lin $^{3}$ \\ 1 Department of Safety, Health and Environmental Engineering, Hungkuang University, \\ Taichung 43302, Taiwan; hmliu@sunrise.hk.edu.tw \\ 2 Hsuteng Consulting International Co., Ltd. Taichung 40764, Taiwan \\ 3 Institute of Environment Engineering and Management, National Taipei University of Technology, \\ Taipei 10643, Taiwan; f10919@ntut.edu.tw (S.-S.C.); lovey1124@gmail.com (S.-Y.Y.); \\ chenghh1126@gmail.com (K.-S.L.) \\ * Correspondence: hhcheng1126@gmail.com; Tel.: +886-4-2461-6260
}

Received: 12 April 2018; Accepted: 30 May 2018; Published: 3 June 2018

\begin{abstract}
Using $\mathrm{Ti}\left(\mathrm{OC}_{4} \mathrm{H}_{9}\right)_{4}$ as a precursor, $\mathrm{Fe}\left(\mathrm{NO}_{3}\right)_{3} \cdot 9 \mathrm{H}_{2} \mathrm{O}$ as the source of iron, and $\mathrm{NH}_{4} \mathrm{NO}_{3}$ as the source of nitrogen, an $\mathrm{Fe} / \mathrm{N}$ codoped $\mathrm{TiO}_{2}$ catalyst was prepared using a sol-gel hydrothermal method. The as-prepared powders were characterized using X-ray powder diffraction, electron spectroscopy for chemical analysis, Fourier-transform infrared spectroscopy, and ultraviolet-visible spectrophotometry. Fe and $\mathrm{N}$ codoping resulted in decreased crystallite size and increased specific surface area. Results of the photocatalytic degradation of acid orange 7 (AO7) in a continuous-flow fluidized-bed reactor indicated that the maximum decolorization (more than $90 \%$ ) of AO7 occurred with the $\mathrm{Fe} / \mathrm{N}-\mathrm{TiO}_{2}$ catalyst (dosage of $20 \mathrm{~g} / \mathrm{L}$ ) when a combination of visible light irradiation for $10 \mathrm{~h}$ HRT (hydraulic retention time), and a heterogeneous system was used. The AO7 degradation efficiency was considerably improved by increasing the hydraulic retention time from 2.5 to $10 \mathrm{~h}$ or by reducing the initial $\mathrm{AO} 7$ concentration from 300 to $100 \mathrm{mg} / \mathrm{L}$. The reaction rate increased with the light intensity and the maximum value occurred at $35 \mathrm{~mW} / \mathrm{cm}^{2}$; moreover, the efficiency of the AO7 degradation increased when the $\mathrm{pH}$ decreased with maximum efficiency at $\mathrm{pH} 3$.
\end{abstract}

Keywords: $\mathrm{Fe} / \mathrm{N}-\mathrm{TiO}_{2}$; sol-gel; hydrothermal; photocatalytic; visible-light

\section{Introduction}

Environmental pollution is a considerable concern in the modern world. An estimated $2 \%$ of dyes produced annually are discharged as effluents from manufacturing plants, whereas $10 \%$ of dyes are discharged from textile and related industries [1]. Effluents generated from textile manufacturing contain a variety of pollutants characterized by deep coloration, high oxygen demand, high $\mathrm{pH}$, large amounts of suspended solids, and low or nonbiodegradability [2,3]. Many methods have been tested to remove dyes from industrial effluents, including biological processes, adsorption, and coagulation. However, these methods still generate a large amount of sludge or solid waste that requires further treatment.

Advanced oxidation processes are a suitable alternative to traditional methods for solving environmental problems caused by the discharge of textile-dyeing wastewater. Titanium dioxide $\left(\mathrm{TiO}_{2}\right)$ is a heterogeneous photocatalysts and $\mathrm{TiO}_{2}$ based photocatalysis is a promising technique for wastewater treatment [4], especially for wastewater containing refractory organic compounds. However, the large band gap for highly oriented $\mathrm{TiO}_{2}$ powders with pure anatase structure and rutile 
are 3.2 and $3.0 \mathrm{eV}$, respectively. Therefore, pure $\mathrm{TiO}_{2}$ can absorb solar light only in the near ultraviolet (UV) region. To modify this property and shift the excitation threshold toward higher wavenumbers, the recombination time of free radicals must be extended or the phase composition must be changed to significantly affect the optical and electrical properties of the material. Doping with different nonmetallic or metallic elements has often been employed to improve photocatalytic activity [5].

Among nonmetallic dopants, doping $\mathrm{TiO}_{2}$ with $\mathrm{N}$ is one of the most effective methods to produce effects from visible light irradiation [6]. However, because the N 2p states are strongly localized at the top of the valence band, the photocatalytic efficiency of $\mathrm{N}$-doped $\mathrm{TiO}_{2}$ decreases. The isolated empty states tend to trap photogenerated electrons, thereby reducing the photogenerated current [7]. Doping $\mathrm{TiO}_{2}$ with two different elements, namely nitrogen and cheaper Fe ions, has attracted interest in computational studies. Several papers have reported that Fe ions can trap holes or electrons at low doping levels, whereas they become recombination centers at high doping levels [8-10]. The photocatalytic activities of these powders are approximately two to four times higher than those of pure anatase $\mathrm{TiO}_{2}$ under visible light irradiation. The synthesis of $\mathrm{TiO}_{2}$ nanoparticles by using a combination of sol-gel and hydrothermal methods is another recent innovation. The sol-gel hydrothermal method combines the advantages of the sol-gel method with high-pressure hydrothermal conditions [11]; particle size and morphology can be controlled during the hydrothermal process [11,12].

In this paper, we present a sol-gel hydrothermal method for the fabrication of $\mathrm{Fe} / \mathrm{N}-\mathrm{TiO}_{2}$ catalysts that respond to visible light. The photocatalytic activity of $\mathrm{Fe} / \mathrm{N}-\mathrm{TiO}_{2}$ was measured for the degradation of acid orange 7 (AO7) in a continuous-flow fluidized-bed system under visible light irradiation. The effects of operational parameters, such as the catalyst activity, dosage, and solution $\mathrm{pH}$, were also examined.

\section{Materials and Methods}

\subsection{Sample Preparation}

$\mathrm{Fe} / \mathrm{N}-\mathrm{TiO}_{2}$ was prepared using a sol-gel hydrothermal method. A suitable amount $(0.1 \mathrm{~mol})$ of titanium tetra-n-butoxide [ $\left.\mathrm{Ti}\left(\mathrm{OC}_{4} \mathrm{H}_{9}\right)_{4}\right]$ (Sigma Aldrich, MO, USA) was dissolved in $100 \mathrm{~mL}$ of anhydrous ethanol (Merck, Darmstadt, Germany) to obtain solution A. Moreover, 0.0012 mol of iron nitrate $\left[\mathrm{Fe}\left(\mathrm{NO}_{3}\right)_{3} \cdot 9 \mathrm{H}_{2} \mathrm{O}\right]$ (Merck, Darmstadt, Germany) and 0.001 mol of ammonium nitrate (Merck, Darmstadt, Germany) were mixed with $2 \mathrm{~mL}$ of distilled water and $10 \mathrm{~mL}$ of acetic acid (Merck, Darmstadt, Germany) to prepare solution B. Then, solution A was slowly added to solution B at a rate of $2 \mathrm{~mL}$ per minute under stirring for up to $48 \mathrm{~h}$. The sample mixture was transferred to a hydrothermal flask to undergo treatment at $100,150,175$, and $200{ }^{\circ} \mathrm{C}$ for $1 \mathrm{~h}$. The resulting $\mathrm{Fe} / \mathrm{N}-\mathrm{TiO}_{2}$ powder was washed with distilled water until a pH of 7 was established and then dried at $80^{\circ} \mathrm{C}$ for $24 \mathrm{~h}$.

\subsection{Characterization}

The band gap of $\mathrm{Fe} / \mathrm{N}-\mathrm{TiO}_{2}$ was measured using a UV-visible spectrophotometer (Cary 300 Bio, Varian, Mulgrave, Victoria, Australia) equipped with an integrating sphere for diffuse reflectance spectra. The chemical composition of $\mathrm{Fe} / \mathrm{N}-\mathrm{TiO}_{2}$ was verified through electron spectroscopy for chemical analysis (ESCA; ESCALAB 250, VG Scientific, UK). Crystal structures were obtained through X-ray diffraction (XRD; Rigaku Co. DMAX 2200VK, Tokyo, Japan) using Cu K $\alpha$ radiation $(\lambda=1.5418 \AA$ ). All peaks measured through XRD were assigned by comparison with those of the Joint Committee on Powder Diffraction Standards (JCPDS 04-002-2678) [13]. The specific surface area (BET, $\mathrm{m}^{2} \mathrm{~g}^{-1}$ ) was calculated using the BET equation, and total pore volume $\left(\mathrm{Vt}, \mathrm{m}^{3} \mathrm{~g}^{-1}\right)$ was evaluated by converting the adsorption amount at $P / P_{0}=0.95$ to the volume of the liquid adsorbate.

\subsection{Photocatalytic Experiments}

The upflow fluidized-bed system is shown in Figure 1. The photocatalytic activities of Fe/N-TiO samples under visible light were evaluated based on the degradation rate of AO7 in a cylindrical quartz 
reactor $(40 / 30 \mathrm{~mm}$ OD/ID; height $=500 \mathrm{~mm})$ containing $20 \mathrm{~g}$ of $\mathrm{Fe} / \mathrm{N}-\mathrm{TiO}_{2}$ and $5 \mathrm{~L}$ of a $200 \mathrm{mg} / \mathrm{L}$ AO7 aqueous solution. The photoreactor was open to the atmosphere, and the quartz reactor was surrounded by 14 light tubes. The visible light tubes were germicidal lamps with a wavelength of $419 \mathrm{~nm}$ (Sankyo Denki, Tokyo, Japan). The light power (approximately $8 \mathrm{~mW} / \mathrm{cm}^{2}$ ) in the center of the reactor in air was measured using a hand-held optical power meter (Model 840-C, Newport, Irvine, CA, USA). The photodegradation rates of AO7 solutions were determined by periodically measuring the absorbance at $\lambda=484 \mathrm{~nm}$ by using a Hach DR $4000 \mathrm{UV}$-visible spectrophotometer (Hach, Loveland, CO, USA).

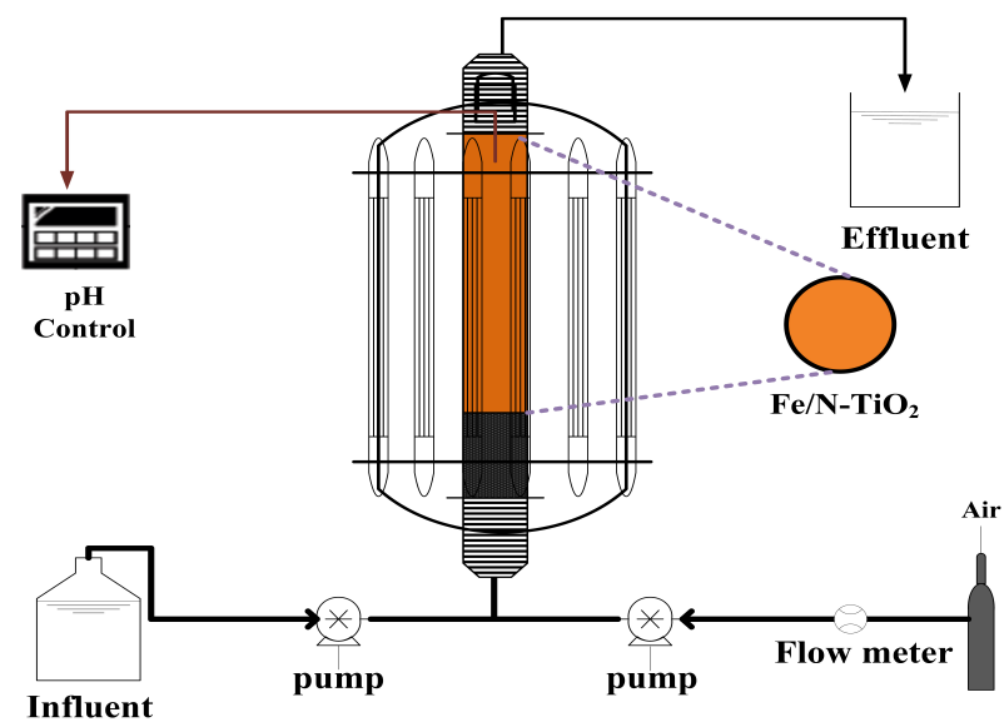

Figure 1. Schematic of the upflow fluidized-bed system.

\section{Results and Discussion}

\subsection{Characterization of the $\mathrm{N} / \mathrm{Fe}-\mathrm{TiO}_{2}$ Samples}

Figure 2a presents the XRD patterns of undoped $\left(\mathrm{TiO}_{2}\right)$ and $\mathrm{Fe} / \mathrm{N}-\mathrm{TiO}_{2}$ particles as a function of the reaction temperature. $\mathrm{Fe} / \mathrm{N}-\mathrm{TiO}_{2}$ particles were readily indexed to the diffraction peaks of the anatase phase (JCPDS 04-002-2678) and exhibited the presence of an intense peak corresponding to the (101) plane. The major peaks observed corresponded to the (101), (004), (200), (105), and (204) planes of the anatase phase [14]. For 100, 150, 175, and $200{ }^{\circ} \mathrm{C} \mathrm{Fe} / \mathrm{N}-\mathrm{TiO}_{2}$ particles, the crystallite sizes were 10.65, 10.79, 12.11, and $13.46 \mathrm{~nm}$, respectively. Smaller crystallite sizes were obtained for the codoped samples, which indicated that the incorporation of Fe and $\mathrm{N}$ ions restricted the growth of $\mathrm{TiO}_{2}$ crystallite and prevented the transformation of anatase to rutile [15]. Deng et al. [16] also investigated the morphology of Fe-doped titania nanotubes synthesized using the sol-gel and hydrothermal methods. They found that the addition of Fe slowed the crystallization process and prevented the growth of crystallite $\mathrm{TiO}_{2}$. The crystallite size of $\mathrm{Fe} / \mathrm{N}-\mathrm{TiO}_{2}$ particles increased with the reaction temperature (Table 1$)$.

To determine whether codoping with $\mathrm{Fe} / \mathrm{N}$ was successful, the surface of $\mathrm{Fe} / \mathrm{N}-\mathrm{TiO}_{2}$ composites was examined through ESCA. The ESCA spectra of Ti $2 p$ in Fe/N-TiO 2 shown in Figure 2(b) reveal that the $\mathrm{Ti} 2 \mathrm{p}_{1 / 2}$ and $\mathrm{Ti} 2 \mathrm{p}_{3 / 2}$ peaks at 464.2 and $458.5 \mathrm{eV}$, respectively, were in a favorable agreement with those previously observed for $\mathrm{Ti}^{4+}$ [17]. The presence of $\mathrm{N}$ in $\mathrm{TiO}_{2}$ particles was substantiated by the $\mathrm{N}$ 1 s spectra and significant peaks around $400 \mathrm{eV}$, which can be attributed to the formation of anionic $\mathrm{N}$ in $\mathrm{O}-\mathrm{Ti}-\mathrm{N}$ linkages [18], whereas the iron peak $(710 \mathrm{eV})$ was attributed to $\mathrm{Fe}^{3+}$, indicating the formation of $\mathrm{Fe}_{2} \mathrm{O}_{3}$ [19]. Saha and Tompkins [20] investigated $\mathrm{N}$ 1s ESCA spectra during the oxidation process of Ti-N and assigned the peaks at $400 \mathrm{eV}$ to be molecularly chemisorbed $\gamma-\mathrm{N}_{2}$. Kim et al. [15] 
reported that the ionic radii of $\mathrm{Fe}^{3+}(0.64 \AA)$ and $\mathrm{Ti}^{4+}(0.68 \AA)$ are similar and that $\mathrm{Fe}^{3+}$ can therefore be incorporated into the lattice of $\mathrm{TiO}_{2}$ to form a Ti-O-Fe bond in $\mathrm{Fe} / \mathrm{N}-\mathrm{TiO}_{2}$. The results indicate that $\mathrm{Fe}$ is present in the form of $\mathrm{Fe}^{3+}$ by replacing $\mathrm{Ti}^{4+}$ in the doped photocatalyst, which may change the charge distribution of atoms on the photocatalyst surface, resulting in enhanced photocatalytic activity. By contrast, the decrease of Ti binding energy upon $\mathrm{N}$-doping could be interpreted as the formation of $\mathrm{O}-\mathrm{Ti}-\mathrm{N}$ in the $\mathrm{TiO}_{2}$ lattice [19], which indicates that nitrogen incorporation can successfully retard the charge recombination at the $\mathrm{TiO}_{2} /$ dye/electrolyte interface. Additionally, the concentrations of $\mathrm{Fe}$ and $\mathrm{N}$ in $\mathrm{Fe} / \mathrm{N}-\mathrm{TiO}_{2}$ determined using ESCA were 5.58 and $5.48 \mathrm{wt} \%$, respectively, which were consistent with the theoretical expectation.
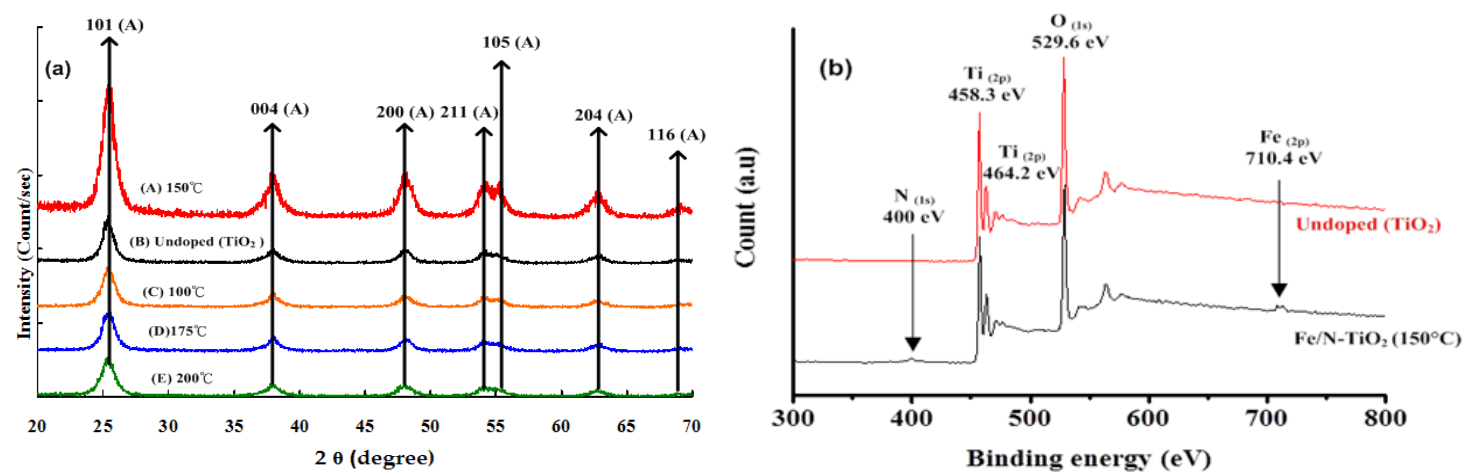

Figure 2. $\mathrm{Fe} / \mathrm{N}-\mathrm{TiO}_{2}$ powders prepared using the sol-gel hydrothermal process: (a) XRD patterns of samples A-E, (b) ESCA spectra of the samples.

Table 1. Physicochemical properties of doped and undoped samples.

\begin{tabular}{cccccc}
\hline \multicolumn{2}{c}{ Sample } & $\begin{array}{c}\text { Crystallite } \\
\text { Size }(\mathbf{n m})\end{array}$ & $\begin{array}{c}\text { BET Surface } \\
\text { Area }\left(\mathbf{m}^{\mathbf{2}} \mathbf{g}^{-\mathbf{1}}\right)\end{array}$ & $\begin{array}{c}\text { Band Gap } \\
(\mathbf{e V})\end{array}$ & $\begin{array}{c}\text { Degradation (\%) } \\
\text { (Batch-Type) }\end{array}$ \\
\hline \multicolumn{2}{c}{ Undoped $\mathrm{TiO}_{2}$} & 30.01 & 56 & 3.20 & 31 \\
$\mathrm{Fe} / \mathrm{N}-\mathrm{TiO}_{2}$ & $100^{\circ} \mathrm{C}$ & 10.65 & 233 & 2.67 & 61 \\
& $150^{\circ} \mathrm{C}$ & 10.79 & 226 & 2.67 & 95 \\
& $175^{\circ} \mathrm{C}$ & 12.11 & 211 & 2.74 & 93 \\
& $200^{\circ} \mathrm{C}$ & 13.46 & 213 & 2.55 & 67 \\
\hline
\end{tabular}

The calculation of the band gap of materials can be conducted using the following formulation: absorption coefficient $(a)$ and the incident photon energy $(h v)$ can be written as $a=B i \cdot\left(h v-E_{g}\right)^{2} / h v$, where $B i$ is the absorption constant for indirect transitions, $h v$ is the photon energy, and $E_{g}$ is the band gap energy [21]. Plots of $(a h v)^{1 / 2}$ versus $h v$ from the spectral data are presented in Figure 3a, which shows the UV-visible spectra of the undoped $\left(\mathrm{TiO}_{2}\right)$ and $\mathrm{Fe} / \mathrm{N}-\mathrm{TiO}_{2}$ particles from 250 to $700 \mathrm{~nm}$. Samples A-E exhibited typical UV-visible spectra for semiconductor materials with a band gap absorption onset at $465,388,464,452$, and $485 \mathrm{~nm}$, which corresponded to energy bandgaps at $2.67,3.20,2.67,2.74$, and $2.55 \mathrm{eV}$, respectively. These results demonstrate that the absorption of doped $\mathrm{TiO}_{2}$ in the visible light region is significantly enhanced compared with that of undoped $\mathrm{TiO}_{2}$, which in turn may considerably increase the photocatalytic activity of $\mathrm{TiO}_{2}$ under visible light irradiation. Fourier-transform infrared (FT-IR) spectrum of the $\mathrm{Fe} / \mathrm{N}-\mathrm{TiO}_{2}$ prepared using the sol-gel hydrothermal method at $150{ }^{\circ} \mathrm{C}$ and the undoped $\mathrm{TiO}_{2}$ over the $400-4000 \mathrm{~cm}^{-1}$ range are shown in Figure 3b. The strong absorption at 3442 and $1640 \mathrm{~cm}^{-1}$ were assigned to the stretching vibration and the bending vibration of $\mathrm{OH}$, respectively, originating from water adsorbed on the samples' surface [15]. The peaks around $1090 \mathrm{~cm}^{-1}$ were attributed to the $\mathrm{N}$ atoms embedded in the $\mathrm{TiO}_{2}$ network. In addition, the small peak observed at $570 \mathrm{~cm}^{-1}$ indicates Fe-O-Ti vibrations [22]. No absorption peak for Fe-N stretching was observed, indicating that Fe did not substitute for Ti at sites where $\mathrm{N}$ atoms substituted for $\mathrm{O}$ atoms. 

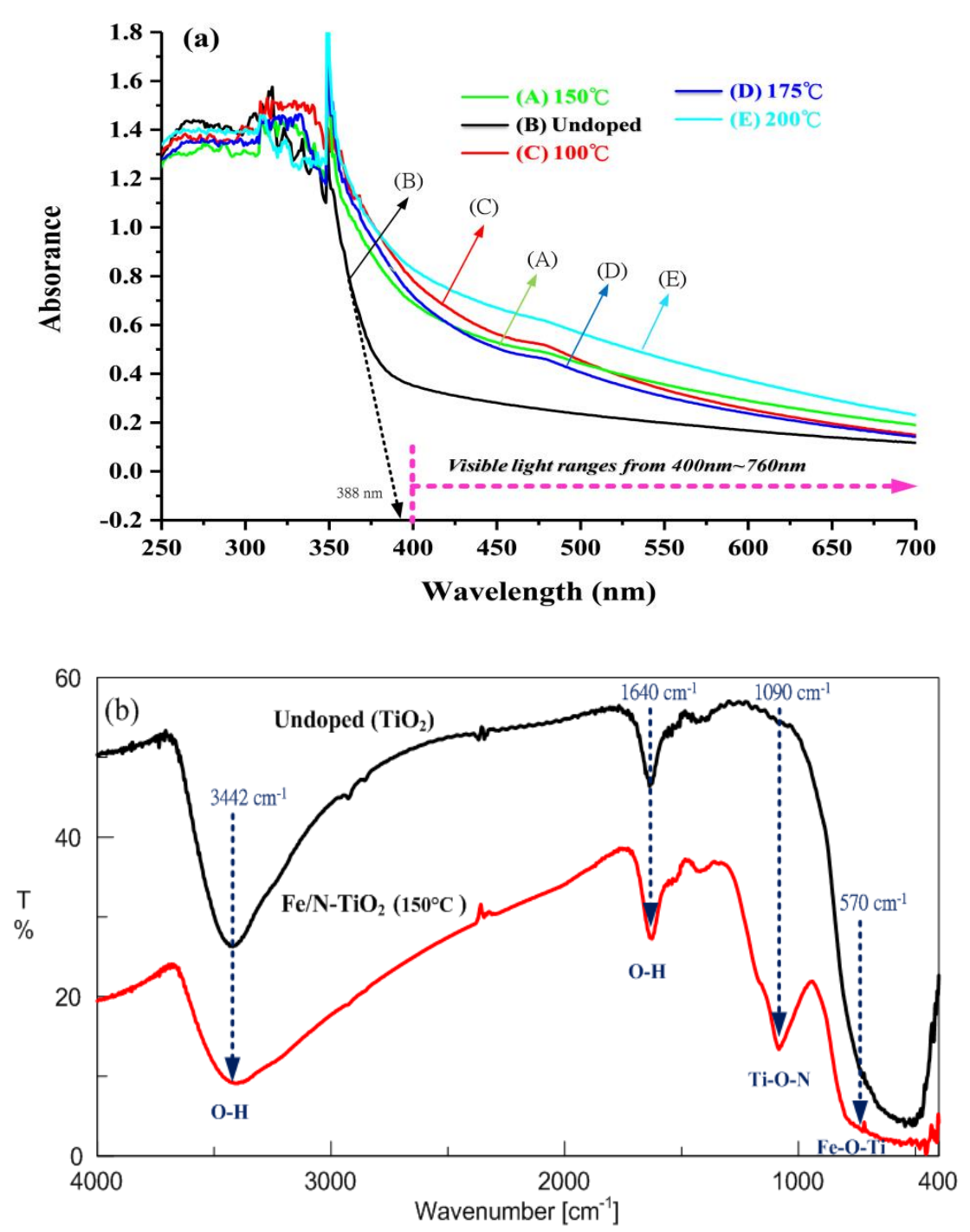

Figure 3. $\mathrm{Fe} / \mathrm{N}-\mathrm{TiO}_{2}$ powders prepared using the sol-gel hydrothermal process: (a) UV-visible reflectance spectra of samples A-E, (b) FT-IR spectra of the samples.

The optimal synthesis temperature of $\mathrm{Fe} / \mathrm{N}-\mathrm{TiO}_{2}$ was determined from batch experiments. Figure 4a shows the photocatalytic $\mathrm{AO} 7$ degradation curves for $\mathrm{Fe} / \mathrm{N}-\mathrm{TiO}_{2}$ catalysts synthesized at different temperatures (see Table 1). The photocatalytic activity evolved as follows: $\mathrm{Fe} / \mathrm{N}-\mathrm{TiO}_{2}\left(150^{\circ} \mathrm{C}\right)$ $>\mathrm{Fe} / \mathrm{N}-\mathrm{TiO}_{2}\left(175^{\circ} \mathrm{C}\right)>\mathrm{Fe} / \mathrm{N}-\mathrm{TiO}_{2}\left(200^{\circ} \mathrm{C}\right)>\mathrm{Fe} / \mathrm{N}-\mathrm{TiO}_{2}\left(100^{\circ} \mathrm{C}\right)>$ undoped $\mathrm{TiO}_{2} . \mathrm{Fe} / \mathrm{N} \mathrm{TiO}_{2}\left(150^{\circ} \mathrm{C}\right)$ exhibited the highest photocatalytic activity and led to $95.2 \%$ AO7 degradation in $5 \mathrm{~h}$. In addition, Figure $4 \mathrm{~b}$ plots $\ln \left(C / C_{0}\right)$ versus time obtained by assuming first-order kinetics for the degradation reaction. $C$ and $C_{0}$ are the $\mathrm{AO} 7$ concentrations at time $t$ and initial concentration, respectively. The plots were almost linear, indicating that the reactions followed pseudo first-order kinetics. The first-order degradation rate constants $(k)$ for $\mathrm{Fe} / \mathrm{N}-\mathrm{TiO}_{2}\left(150{ }^{\circ} \mathrm{C}\right), \mathrm{Fe} / \mathrm{N}-\mathrm{TiO}_{2}\left(175{ }^{\circ} \mathrm{C}\right), \mathrm{Fe} / \mathrm{N}-\mathrm{TiO}_{2}\left(200{ }^{\circ} \mathrm{C}\right)$, $\mathrm{Fe} / \mathrm{N}-\mathrm{TiO}_{2}\left(100{ }^{\circ} \mathrm{C}\right)$, and undoped $\mathrm{TiO}_{2}$ catalysts were $5.64 \times 10^{-2}, 4.57 \times 10^{-2}, 2.23 \times 10^{-2}$, $1.36 \times 10^{-2}$, and $8.53 \times 10^{-1} \mathrm{~min}^{-1}$, respectively. This suggests that codoping of Fe and $\mathrm{N}$ narrows the $\mathrm{TiO}_{2}$ band gap. Cong et al. [23] reported that the overlap of the Ti-d orbital of $\mathrm{TiO}_{2}$ and the doped metal d orbital leads to a narrowing of the $\mathrm{TiO}_{2}$ band gap in $\mathrm{TiO}_{2}$ implanted with metal ions, allowing the absorption of visible light. Therefore, $\mathrm{N}$ and $\mathrm{Fe}$ were incorporated into the $\mathrm{TiO}_{2}$ framework, narrowing the band gap of $\mathrm{TiO}_{2}$ to $2.67 \mathrm{eV}$ (Table 1 ) and causing a large red shift, which in turn caused a much narrower band gap and greatly improved photocatalytic activity. By contrast, it inhibits the recombination of photogenerated electrons and holes. Fe ions with a suitable concentration can trap 
photogenerated electrons, which enhances the utilization efficiency of the photogenerated electron and hole [24]. Consequently, under these experimental conditions, $\mathrm{Fe} / \mathrm{N}-\mathrm{TiO}_{2}\left(150^{\circ} \mathrm{C}\right)$ was optimal for AO7 removal after $5 \mathrm{~h}$ of visible light irradiation time.

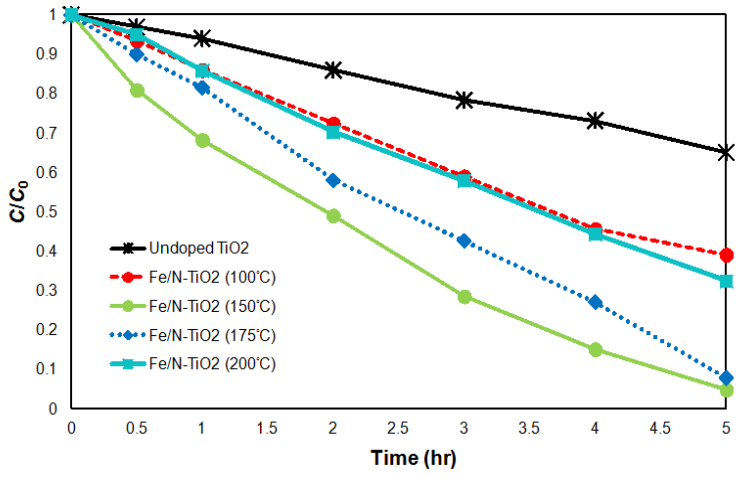

(a)

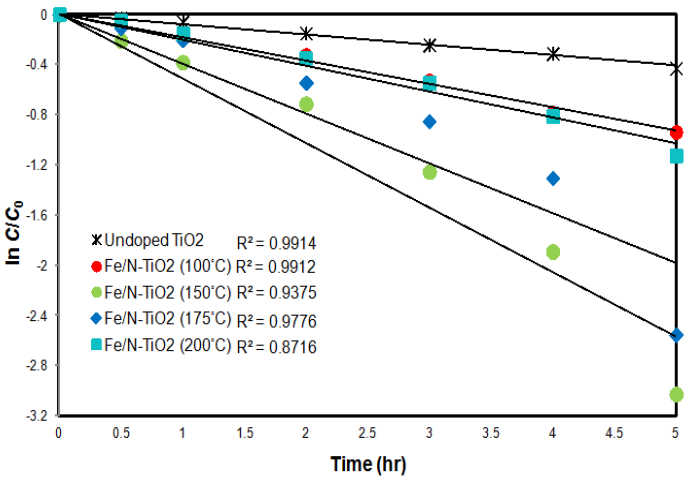

(b)

Figure 4. (a) $\mathrm{AO} 7$ degradation curves for $\mathrm{Fe} / \mathrm{N}-\mathrm{TiO}_{2}$ catalysts synthesized at different temperatures; (b) logarithmic AO7 decay as a function of time. (Experimental condition: $\mathrm{pH}=3$, initial AO7 concentration $=10 \mathrm{mg} / \mathrm{L}$, catalyst dosage $=0.1 \mathrm{~g} / \mathrm{L}$ ).

\subsection{Degradation of AO7 in a Continuous-Flow Fluidized-Bed System}

The optimal $\mathrm{Fe} / \mathrm{N}-\mathrm{TiO}_{2}\left(150{ }^{\circ} \mathrm{C}\right)$ catalyst was selected for photocatalytic activity tests of the degradation of AO7. The effect of the initial $\mathrm{AO} 7$ concentration on the photocatalytic degradation efficiency was examined for concentrations ranging from 100 to $300 \mathrm{mg} / \mathrm{L}$ with an $\mathrm{Fe} / \mathrm{N}-\mathrm{TiO}_{2}\left(150{ }^{\circ} \mathrm{C}\right)$ dosage of $20 \mathrm{~g} / \mathrm{L}$, a hydraulic retention time (HRT) of $10 \mathrm{~h}$, a pH of 3, and a visible light intensity of $35 \mathrm{~mW} / \mathrm{cm}^{2}$. Figure 5 a shows the $\mathrm{AO} 7$ removal efficiency and observed rate constant $\left(K_{\mathrm{obs}}\right)$ as a function of the initial $\mathrm{AO} 7$ concentration at a $\mathrm{pH}$ of 3 and with an HRT of $10 \mathrm{~h}$. The degradation rate of AO7 decreased when the initial AO7 concentration increased. The number of photons decreased because of the decreasing intensity of the visible light, leading to a decrease in the formation of hydroxyl radicals, which ultimately reduced AO7 removal efficiency [25]. Moreover, the reaction rate also increased when the visible light intensity increased, and the maximum rate was reached for an irradiation of $35 \mathrm{~mW} / \mathrm{cm}^{2}$, as illustrated in Figure $5 \mathrm{~b}$. This indicates that the rate of photons per unit area of catalyst powder increased with the light intensity [26], and there was a corresponding increase in photocatalytic degradation rate of AO7.

To study the effect of $\mathrm{pH}$ on degradation efficiency, experiments were performed under visible light at $\mathrm{pH}$ values from 3 to 10 with constant concentrations of $\mathrm{AO}$ and $\mathrm{Fe} / \mathrm{N}-\mathrm{TiO}_{2}\left(150{ }^{\circ} \mathrm{C}\right)$ catalyst. The results in Figure 6a indicate that the photodegradation efficiency for $\mathrm{AO} 7$ increased as the $\mathrm{pH}$ decreased, with maximum efficiency $(88 \%)$ at $\mathrm{pH} 3$. The degradation rates for the continuous-flow photoreactor evolved as follows: $\mathrm{pH} 3>\mathrm{pH} 7>\mathrm{pH} 10$. In addition, increasing the HRT from 2.5 to $10 \mathrm{~h}$ increased the $\mathrm{AO} 7$ removal efficiency from $32 \%$ to $88 \%$ at $\mathrm{pH} 3$. Explaining the effect of $\mathrm{pH}$ on the dye photodegradation efficiency is difficult because of the multiple roles of $\mathrm{H}^{+}$ions, but $\mathrm{pH}$ change is related to the charge in the functionalized surface of the solid catalyst according to the following reactions [27]:

$$
\begin{array}{cc}
\mathrm{TiOH}+\mathrm{H}^{+} \leftarrow \rightarrow \mathrm{TiOH}_{2}{ }^{+}, & \mathrm{pH}<\mathrm{pH}_{\zeta} \\
\mathrm{TiOH}+\mathrm{OH}^{-} \leftarrow \rightarrow \mathrm{TiO}^{-}+\mathrm{H}_{2} \mathrm{O}, & \mathrm{pH}>\mathrm{pH}_{\zeta}
\end{array}
$$




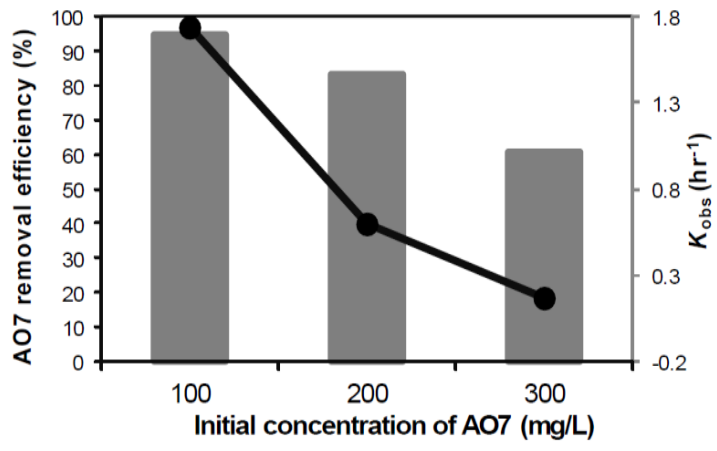

(a)

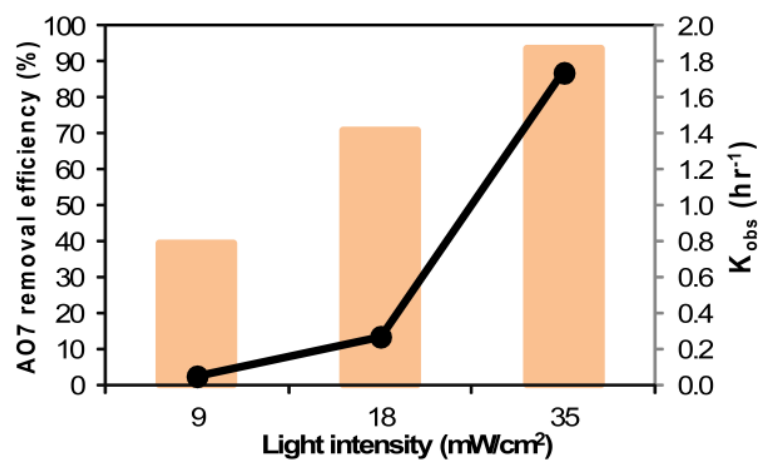

(b)

Figure 5. (a) AO7 removal efficiency and $K_{\mathrm{obs}}$ as a function of initial concentration, (b) effect of visible light intensity on AO7 removal efficiency and $K_{\mathrm{obs}}$ (Experimental condition: $\mathrm{pH}=3, \mathrm{HRT}=10 \mathrm{~h}$, catalyst dosage $=20 \mathrm{~g} / \mathrm{L})$.

According to Equation (1), when $\mathrm{TiO}_{2}$ is suspended in an acidic solution ( $\mathrm{pH}<$ point of zero charge, $\mathrm{pH}_{\zeta}$ ), the surface charge of $\mathrm{TiO}_{2}$ becomes positive. Conversely, when $\mathrm{TiO}_{2}$ is suspended in a basic solution $\left(\mathrm{pH}>\mathrm{pH}_{\zeta}\right)$, the surface charge becomes negative, as shown in Equation (2). Figure $6 \mathrm{~b}$ shows that $\mathrm{pH}_{\zeta}$ for the $\mathrm{Fe} / \mathrm{N}-\mathrm{TiO}_{2}$ was 6 . Therefore, the surface of the catalyst was positively charged at $\mathrm{pH}<6$ and negatively charged at $\mathrm{pH}>6$. AO7 is an anionic dye and was negatively charged under the experimental conditions used because of the $\mathrm{SO}_{3}{ }^{2-}$ groups. Therefore, electrostatic interactions between the $\mathrm{Fe} / \mathrm{N}-\mathrm{TiO}_{2}$ catalysts and the sulfonate groups resulted in adsorption at $\mathrm{pH}<6$ and enhanced degradation efficiency. Conversely, adsorption of $\mathrm{AO} 7$ onto $\mathrm{Fe} / \mathrm{N}-\mathrm{TiO}_{2}$ surfaces was weak at $\mathrm{pH}>6$ because of Coulombic repulsion between the negatively charged $\mathrm{Fe} / \mathrm{N}-\mathrm{TiO}_{2}$ and the AO7 molecules. Therefore, the degradation efficiency decreased.

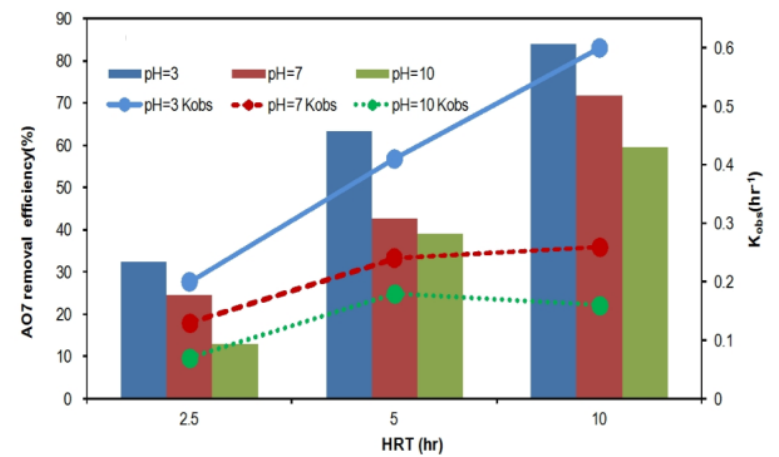

(a)

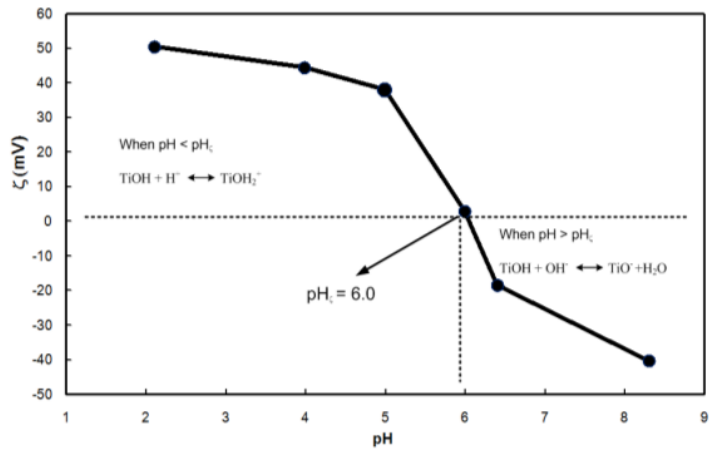

(b)

Figure 6. (a) Effect of $\mathrm{pH}$ on AO7 removal efficiency and $K_{\mathrm{obs}}$ as a function of HRT, (b) Zeta potential (द) of $\mathrm{Fe} / \mathrm{N}-\mathrm{TiO}_{2}$ (initial $\mathrm{AO} 7$ concentration $=200 \mathrm{mg} / \mathrm{L}$, catalyst dosage $=20 \mathrm{~g} / \mathrm{L}$, visible light intensity $\left.=35 \mathrm{~mW} / \mathrm{cm}^{2}\right)$.

\section{Conclusions}

$\mathrm{Fe} / \mathrm{N}-\mathrm{TiO}_{2}$ catalysts were synthesized using a combination of sol-gel and hydrothermal processes. The average size and distribution of the $\mathrm{Fe} / \mathrm{N}-\mathrm{TiO}_{2}$ particles synthesized was approximately $10-15 \mathrm{~nm}$. The average size of the particles synthesized increased with the reaction temperature, and the absorption edge of $\mathrm{Fe} / \mathrm{N}-\mathrm{TiO}_{2}$ catalysts was red-shifted toward $480 \mathrm{~nm}$. The $\mathrm{Fe} / \mathrm{N}-\mathrm{TiO}_{2}$ photocatalyst exhibited favorable photocatalytic activity for the degradation of AO7 in a continuous-flow fluidized-bed system under visible light. The experimental results revealed that the optimal dosage of $\mathrm{Fe} / \mathrm{N}-\mathrm{TiO}_{2}$ was $20 \mathrm{~g} / \mathrm{L}$, and that $\mathrm{AO} 7$ degradation efficiency was substantially improved by increasing 
HRT from 2.5 to $10 \mathrm{~h}$ or by reducing initial AO7 concentration from 300 to $100 \mathrm{mg} / \mathrm{L}$. Additionally, the degradation efficiency of AO7 increased as the $\mathrm{pH}$ decreased, with a maximum efficiency at $\mathrm{pH} 3$.

Author Contributions: All the authors have contributed equally to the realization of work.

Funding: This study was supported by grant from Hsuteng Consulting International Co., Ltd.

Acknowledgments: The authors gratefully acknowledge experimental apparatus support from Institute of Environment Engineering and Management, National Taipei University of Technology.

Conflicts of Interest: The authors declare no conflicts of interest.

\section{References}

1. Easton, J.R.; Waters, B.D.; Churchley, J.H.; Harrison, J. Colour in dyehouse effluent. In Society of Dyers and Colourists; Cooper, P., Ed.; The Alden Press: Oxford, UK, 1995.

2. Liu, C.C.; Hsieh, Y.H.; Lai, P.F.; Li, C.H.; Kao, C.L. Photodegradation treatment of azo dye wastewater by $\mathrm{UV} / \mathrm{TiO}_{2}$ process. Dyes Pigm. 2006, 68, 191-195. [CrossRef]

3. Lu, X.; Yang, B.; Chen, J.; Sun, R. Treatment of wastewater containing azo dye reactive brilliant red X-3B using sequential ozonation and upflow biological aerated filter process. J. Hazard. Mater. 2009, 161, 241-245. [CrossRef] [PubMed]

4. Jothiramalingam, R.; Wang, M.K. Synthesis, characterization and photocatalytic activity of porous manganese oxide doped titania for toluene decomposition. J. Hazard. Mater. 2007, 147, 562-569. [CrossRef] [PubMed]

5. American Society for Testing and Material. Powder Diffraction Files; Joint Committee on Powder Diffraction Standards: Swarthmore, PA, USA, 1999; pp. 3-888.

6. McManamon, C.; Delaney, P.; Morris, M.A. Photocatalytic properties of metal and non-metal doped novel sub $10 \mathrm{~nm}$ titanium dioxide nanoparticles on methyl orange. J. Colloid Interface Sci. 2013, 411, 169-172. [CrossRef] [PubMed]

7. Irie, H.; Watanabe, Y.; Hashimoto, K. Nitrogen-concentration dependence on photocatalytic activity of $\mathrm{TiO}_{2-x} \mathrm{~N}_{x}$ powders. J. Phys. Chem. B 2003, 107, 5483-5486. [CrossRef]

8. Lin, Z.; Orlov, A.; Lambert, R.M.; Payne, M.C. New Insights into the origin of visible light photocatalytic activity of nitrogen-foped and oxygen-feficient snatase $\mathrm{TiO}_{2}$. J. Phys. Chem. B 2005, 109, 20948-20952. [CrossRef] [PubMed]

9. Zhou, M.; Yu, J.; Cheng, B. Effects of Fe-doping on the photocatalytic activity of mesoporous $\mathrm{TiO}_{2}$ powders prepared by an ultrasonic method. J. Hazard. Mater. 2006, 137, 1838-1847. [CrossRef] [PubMed]

10. Yu, J.; Xiang, Q.; Zhou, M. Preparation, characterization and visible-light-driven photocatalytic activity of Fe-doped titania nanorods and first-principles study for electronic structures. Appl. Catal. B 2009, 90, 595-602. [CrossRef]

11. Wen, L.; Liu, B.; Zhao, X.; Kazuya, N.; Taketoshi, M.; Akira, F. Synthesis, characterization, and photocatalysis of Fe-doped $\mathrm{TiO}_{2}$ : A combined experimental and theoretical study. Int. J. Photoenergy 2012, 2012, 1-10.

12. Dang, T.M.H.; Trinh, V.D.; Bui, D.H.; Phan, M.H.; Huynh, D.C. Sol-gel hydrothermal synthesis of strontium hexaferrite nanoparticles and the relation between their crystal structure and high coercivity properties. Adv. Nat. Sci. Nanosci. Nanotechnol. 2012, 2, 1-7. [CrossRef]

13. Kim, H.J.; Bae, S.B.; Bae, D.S. Synthesis and characterization of Ru doped $\mathrm{TiO}_{2}$ nanoparticles by a sol-gel and a hydrothermal process. J Mater. 2010, 9, 9-12.

14. Bickley, R.I.; Gonzalez-Carreno, T.; Lees, J.S.; Palmisano, L.; Tilley, R.J.D. A structural investigation of titanium dioxide photocatalysts. J. Solid State Chem. 1991, 92, 178-190. [CrossRef]

15. Kim, T.H.; Rodríguez-González, V.; Gyawali, G.; Cho, S.H.; Sekino, T.; Lee, S.W. Synthesis of solar light responsive $\mathrm{Fe}, \mathrm{N}$ codoped $\mathrm{TiO}_{2}$ photocatalyst by sonochemical method. Catal. Today 2013, 212, 75-80. [CrossRef]

16. Deng, L.; Wang, S.; Liu, D. Synthesis, characterization of Fe-doped $\mathrm{TiO}_{2}$ nanotubes with high photocatalytic activity. Catal. Lett. 2009, 129, 513-518. [CrossRef]

17. Cheng, H.H.; Chen, S.S.; Cheng, Y.W.; Tseng, W.L.; Wang, Y.H. Liquid-phase non-thermal plasma-prepared $\mathrm{N}$-doped $\mathrm{TiO}_{2}$ for azo dye degradation with the catalyst separation system by ceramic membranes. Water Sci. Technol. 2010, 62, 1060-1066. [CrossRef] [PubMed] 
18. Yang, G.; Jiang, Z.; Shi, H.; Xiao, T.; Yan, Z. Preparation of highly visible-light active N-doped $\mathrm{TiO}_{2}$ photocatalyst. J. Mater. Chem. 2010, 20, 5301-5309. [CrossRef]

19. Hsu, B.C.; Chen, S.S.; Su, C.C.; Li, Y.C. Preparation and characterization of nanocrystalline Fe/N Codoped titania. Ferroelectrics 2009, 381, 51-58. [CrossRef]

20. Saha, N.C.; Saha, H.G. Titanium nitride oxidation chemistry: An X-ray photoelectron spectroscopy study. J. Appl. Phys. 1992, 72, 3072-3079. [CrossRef]

21. Tian, F.; Wu, Z.; Tong, Y.; Wu, Z.; Cravotto, G. Microwave-assisted synthesis of carbon-based (N, Fe)-codoped $\mathrm{TiO}_{2}$ for the photocatalytic degradation of formaldehyde. Nanoscale Res. Lett. 2010, 10, 1-12. [CrossRef] [PubMed]

22. Ishii, M.; Nakahira, M.; Yamanaka, T. Infrared absorption spectra and cation distributions in $(\mathrm{Mn}, \mathrm{Fe})_{3} \mathrm{O}_{4}$. Solid State Commun. 1972, 1, 209-212. [CrossRef]

23. Cong, Y.; Zhang, J.; Chen, F.; Anpo, M.; He, D. Preparation, photocatalytic activity, and mechanism of nano- $\mathrm{TiO}_{2}$ Codoped with nitrogen and iron (III). J. Phys. Chem. C 2007, 111, 10618-10623. [CrossRef]

24. Nguyen, V.N.; Nguyen, N.K.T.; Nguyen, P.H. Hydrothermal synthesis of Fe-doped $\mathrm{TiO}_{2}$ nanostructure photocatalys. Adv. Nat. Sci. Nanosci. Nanotechnol. 2011, 2,1-4.

25. Daneshvar, N.; Aber, S.; Hosseinzadeh, F. Study of C.I. acid orange 7 removal in contaminated water by photo oxidation processes. Glob. Nest J. 2008, 10, 16-23.

26. Sharma, R.; Heda, L.C.; Ameta, S.C.; Sharma, S. Use of zinc oxide as photocatalyst for photodegradation of copper soap derived from azadirecta indica (neem) oil. Res. J. Pharm. Biol. Chem. Sci. 2013, 4, 537-548.

27. Wang, W.Y.; Ku, Y. Effect of solution $\mathrm{pH}$ on the adsorption and photocatalytic reaction behaviors of dyes using $\mathrm{TiO}_{2}$ and Nafion-coated $\mathrm{TiO}_{2}$. Colloid Surf. A Physicochem. Eng. Asp. 2007, 302, 261-268. [CrossRef]

(C) 2018 by the authors. Licensee MDPI, Basel, Switzerland. This article is an open access article distributed under the terms and conditions of the Creative Commons Attribution (CC BY) license (http:/ / creativecommons.org/licenses/by/4.0/). 